\title{
Original
}

\section{A STUDY OF MUTATIONAL PHASE OF STREPTOCOCCUS MUTANS : CARIES-REDUCING EFFECT OF MUTATIONAL PHASE III OF STR. MUTANS IN ANIMALS}

\author{
Takashi TSURUMIZU*, Yoshio FUKUDA* Makoto SATO** and Fumiko OZAKI**
}

\begin{abstract}
Mutational phase III strains reduced caries in experimental animals. The proliferation in phase I was extremely inhibited in the presence of phase III in the oral cavity of hamsters, resulting in suppressed caries induction by phase I. In rats, the phase III strain induced from Str. mutans isolated from a rat could inhibit the growth of Str. mutans indigeneous in rats, and showed a caries-reducing effect, but the phase III strain induced from Str. mutans isolated from a human failed to exhibit the caries-reducing effect. There seemed to be a considerable degree of specificity between Str. mutans and the host.
\end{abstract}

\section{Introduction}

Mutants of Str. mutans were isolated with a mutagenic agens, and they were designated phase I, phase II, and phase III according to their properties ${ }^{1)}$. It was demonstrated that phase III strains lost their cariogenicity and suppressed the growth and plaque formation of phase I strains ${ }^{1)}$. In the study, the inhibition of dental caries in animals using phase III strains was investigated.

\section{Materials and Methods}

Twe types of experimental models, hamsters and rats, were used.

1) Hamsters and experimental design.

Two kinds of experiments were employed as shown in Fig. 1. A battery of test organisms of Str. mutans 10449 phase I and phase III were used. For the duration of the experiment, hamsters were fed diet 2000 of Keyes and Jordan ${ }^{2)}$. Diet and distilled water were provided and libitum.

Exp.-1. In order to depress the indigenous bacterial flora, streptomycin sulfate $(200 \mu \mathrm{g} / \mathrm{ml})$ was administered prior to inoculation of the test organisms during two days. At weaning, 21 days pf age, the hamsters were divided into two groups, experimental and control, and each hamster of both groups was inoculated in its pouch with $0.2 \mathrm{ml}$ of 24 hour culture of the phase $\mathrm{I}$ strain in $\mathrm{TYC}^{\text {s) }}$ broth once a day for five days.

The establishment of the inoculated phase I strain was examined on the day after the last inoculation and on the day the animals were killed. Oral swab samples from all hamsters of both groups were put into $10 \%$ glycerol-3\% peptone solutions. Each sample was smeared on TYC agar

* Chiba Prefectural Institute of Public Health, 666-2 Nitona-cho, Chiba-shi, Chiba.

** Department of Preventive Dentistry and Public Health, Faculty of Dentistry, Tokyo Medical and Dental University, 1-5-45 Yushima, Bunkyo-ku, Tokyo.

*千莱累街生研究所

**東京医科齿科大学齿学部予防齿科学踖座（主任：岡田昭五郎教授） 昭和 57 年 8 月 19 日受付 

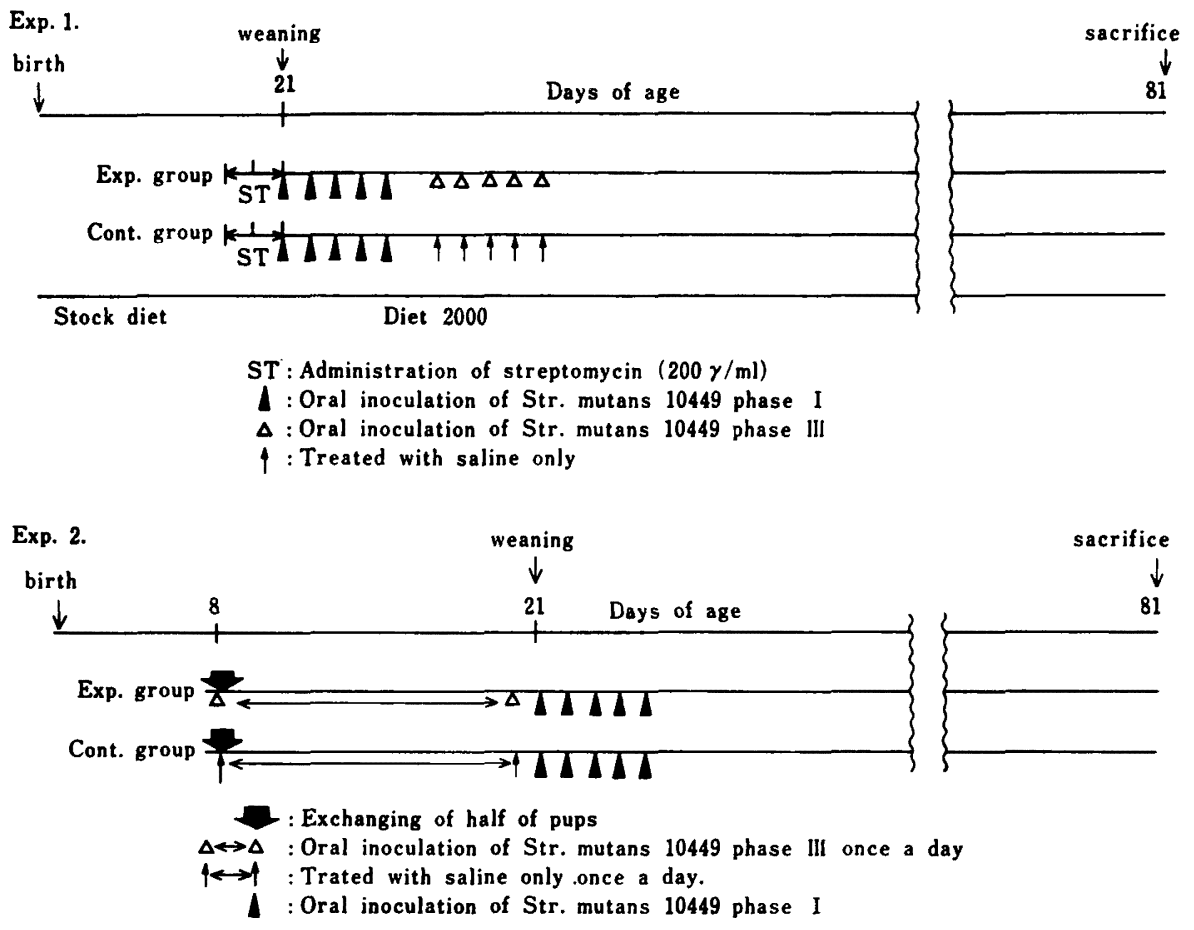

Fig. 1 Experimental designs employed in hamsters

plates and the colonies grown on them were observed.

The phase III strain of 24 hour culture in TYC broth was inoculated into the hamsters of the experimental group and saline into those of control grout for five consecutive days from two days after the last inoculation of the phase I strain.

Exp. 2. Two females, each with a litter of eight pups, were derived from our own breeding colony. Half of the pups of each female were at 8 days of age when molars began to erupt. Pups of the experimental group were consecutively infected with $0.03 \mathrm{ml}$ of the phase III strain, and pups of the control group with $0.03 \mathrm{ml}$ of saline for 14 days till weaning. The establishment of the phase III strain in the experimental group was examined as described above in Exp.-1. The phase I strain was inoculated for another five days into hamsters of both experimental and control groups (Fig. 1). The establishment of the phase I strain was examined in both groups on the day the animals were killed.

In both Exp. 1 and 2, the period of experiment was 60 days after weaning. At the end of the experiments, the hamsters were killed, and the mandibles were removed. After the soft tissue was removed from them by autoclaving for 2 minutes at $121^{\circ} \mathrm{C}$ and they were washed and air-dried, carious lesions were scored on the mandibular molars of the jaws by method of Keyes").

2) Rats and experimental design.

Twenty-one day wistar rats, derived from our own breeding colony, were used in this experiment. They harbor R-group indigenous Str. mutans in their mouths at weaning. They were divided into three groups, two experimental groups and one control group. The rats in the experimental groups were inoculated with Str. mutans 10449 phase III or Str. mutans RC-20 phase III. The 
inoculations were repeated once a day for 8 days $^{5)}$. The control group received no treatment. For inoculation, the organisms were cultured in TYC broth $(300 \mathrm{ml})$ for 24 hours at $37^{\circ} \mathrm{C}$, centrifuged, and then washed and suspended in $10 \mathrm{ml}$ of sterilized saline. $0.2 \mathrm{ml}$ of the cell suspension were directly applied into the rat's mouth with sterilized cotton rolls. During the experiment, rats were fed cariogenic died $6 \mathrm{PMV}^{6}$. Diet and distilled water were provided ad libitum. The experimental period was 30 days after weaning (at 21 days old), and at the end of the experiment, the rats were killed and the jaws were removed. Individual jaws were stained with $0.5 \%$ basic fuchsin solution ${ }^{7}$, Sectioned with a thin-sectioning machine* into about $200 \mu$ thickness, and the fissures of the molars were scored for early-lesion caries ${ }^{8)}$ with a dissection microscope. At weaning on the 10th day and at the end of the experiment, oral swabbings were taken from all rats for bacteriological survey. The number of colonies of total streptococci on Mitis Salivarius agar** and wild Str. mutans on TYC agar were determined. On the 10 th and the end of experiment, the establishment of inoculated phase III strain was investigated.

\section{Results}

The caries-reducing-effect of phase III strains of Str. mutans was investigated in hamsters and rats.

1) Hamsters and (Table 1)

In Exp. 1, all hamsters were infected with Str. mutans 10449 phase I for 5 days after weaning. All hamsters had this strain in their mouths at weaning. In the experimental group, hamsters were received following inoculation with Str. mutans 10449 phase II. When killed, although all hamsters of the control group harbored phase I strains, none of the experimental group harbored them in their mouths. The caries scores of the experimental group were much lawer than those of the control group, as seen in Table 1.

Table 1 Caries scores on the mandibular molar surfaces of hamsters infected with Str. mutans 10449 phase I and phase III

\begin{tabular}{l|c|c|crrr}
\hline \multirow{2}{*}{ Group } & $\begin{array}{c}\text { No. of } \\
\text { animals }\end{array}$ & $\begin{array}{c}\text { Weight } \\
\text { gain } \\
(\mathbf{g})\end{array}$ & \multicolumn{3}{|c|}{ Caries scores according to Keyes } \\
\cline { 4 - 6 } & 8 & Total & $\begin{array}{c}\text { 1st } \\
\text { molar }\end{array}$ & $\begin{array}{c}\text { 2nd } \\
\text { molar }\end{array}$ & $\begin{array}{c}\text { 3rd } \\
\text { molar }\end{array}$ \\
\hline Experimental & 83.4 & 71.67 & 3.68 & 16.54 & 51.45 \\
Control & 8 & 62.1 & 247.51 & 76.23 & 78.13 & 93.15
\end{tabular}

Exp. 1. Str. mutans 10449 phase III was inoculated after the establishment of Str. mutans 10449 phase I.

\begin{tabular}{l|c|c|crrr}
\hline \multirow{2}{*}{ Group } & \multirow{2}{*}{$\begin{array}{c}\text { No. of } \\
\text { animals }\end{array}$} & $\begin{array}{c}\text { Weight } \\
\text { gain } \\
(\mathbf{g})\end{array}$ & \multicolumn{3}{|c}{ Caries scores according to Keyes } \\
\cline { 5 - 7 } & & Total & $\begin{array}{c}\text { 1st } \\
\text { molar }\end{array}$ & $\begin{array}{c}\text { 2nd } \\
\text { molar }\end{array}$ & $\begin{array}{c}\text { 3rd } \\
\text { molar }\end{array}$ \\
\hline Experimental & 8 & 63.5 & 50.72 & 3.92 & 9.90 & 36.90 \\
Control & 8 & 62.8 & 177.34 & 34.20 & 59.11 & 84.03
\end{tabular}

Exp. 2. Str. mutans 10449 phase III was inoculated before the inoculation of Str. mutans 10449 phase I.

* Bronwill Scientific, Rochester, N. Y.

** BBL, Baltimore, MD. 
In Exp. 2, the phase III strain was confirmed in the mouth of all hamsters at weaning. After weaning, phase I strain was given for the next 5 days to both groups. The first procedure in the experimental group, inoculation of the phase III strain, suppressed the phase I strain. That is, the phase I strain was not found at all in the mouths of hamsters of the experimental group when killed, although all hamster in the control group had the phase Istrain. The caries scores were also much lower in the experimental group than in the control group, in which the phase I strain remained till the end of the experiment (Table 1).

Table 2 Comparison of caries-reducing effect of Str. mutans 10449 phase III and Str. mutans $\mathrm{RC}-20$ phase $\mathrm{II}$ in rats

\begin{tabular}{cclccc}
\hline Group & $\begin{array}{c}\text { No. of } \\
\text { rats }\end{array}$ & \multicolumn{1}{c}{$\begin{array}{c}\text { Inoculated } \\
\text { organism }\end{array}$} & $\begin{array}{c}\text { Weight } \\
\text { gain }(\mathrm{g})\end{array}$ & $\begin{array}{c}\text { Prevalence } \\
(\%)\end{array}$ & $\begin{array}{c}\text { Caries scores } \\
\text { (No. of carious } \\
\text { fissures per head) }\end{array}$ \\
\hline 1 & 20 & 10449 phase III & 30.1 & 95 & 5.05 \\
2 & 19 & RC-20 phase III & 30.0 & 79 & 2.75 \\
3 & 20 & Control & 33.7 & 100 & 4.80
\end{tabular}

Table 3 Comparison of the number of wile Str. mutans and total streptococci in the mouths of rats

\begin{tabular}{|c|c|c|c|c|c|c|c|c|c|}
\hline \multirow[b]{2}{*}{$\begin{array}{l}\text { Experimental } \\
\text { Day }\end{array}$} & \multicolumn{3}{|c|}{ Group 1 Colony count } & \multicolumn{3}{|c|}{ Group 2 Colony count } & \multicolumn{3}{|c|}{ Group 3 Colony count } \\
\hline & $\begin{array}{c}\text { wild* } \\
\text { S. mutans }\end{array}$ & $\begin{array}{l}\text { total* } \\
\text { Strept }\end{array}$ & $\frac{\text { s. mutans }}{\text { total }}$ & $\begin{array}{c}\text { wild } \\
\text { S. mutans }\end{array}$ & $\begin{array}{l}\text { total } \\
\text { Strept }\end{array}$ & 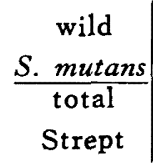 & $\begin{array}{c}\text { wild } \\
\text { S. mutans }\end{array}$ & $\begin{array}{l}\text { total } \\
\text { Strept }\end{array}$ & $\begin{array}{c}\frac{\text { wild }}{S .} \text { mutans } \\
\text { total } \\
\text { Strept }\end{array}$ \\
\hline At weaning & 4.80 & 7.03 & 0.01 & 4.52 & 6.72 & 0.01 & 4.63 & 6.46 & 0.01 \\
\hline 10 & 5.62 & 6.61 & 0.10 & 4.74 & 6.67 & 0.01 & 5.41 & 6.85 & 0.04 \\
\hline At sacrifice & 6.39 & 7.07 & 0.21 & 6.22 & 6.99 & 0.17 & 6.04 & 6.76 & 0.19 \\
\hline
\end{tabular}

* Colony counts of wild Str. mutans and total streptococci are given in logarithm.

2) Rats (Table 2).

As shown in Table 2, the score of caries of the second group rats infected with the phase III mutant of R-group Str. mutans RC-20 was significantly smoller $(\mathrm{p}<0.01)$ than the scores of the third group and the control rats. But the caries score of the first group rats infected with the phase III mutant of Human-group Str. mutans 10449 was the same of that of the control rats.

The proliferation of the indigenous Str. mutans was less in the second group rats than in the first group and control rats two days after the last inoculation of test organisms, on the 10 th day of the experiment, as shomn in Table 3. But on the last day of the experiment, recoverable number of indigenous Str. mutans were almost the same among the three groups. No distinct

Table 4 Percentage of rats in which phase III strains were recoverable

\begin{tabular}{cccc}
\hline Group & At weaning & 10th Day & At sacrifice \\
\hline 1 & - & $40.4(8 / 20)$ & $20.0(4 / 20)$ \\
2 & - & $63.2(12 / 19)$ & $21.1(4 / 19)$
\end{tabular}

differences were observed between the establishment of Str. mutans RC-20 phase III and 10449 phase III. On the 10 th day of experiment, RC-20 phase III strain seemed to adapt better than 10449 phase III strain in the mouth of rats, but on the last day of the experi- 
ment, the establishment rates of both phase III strains were decreased to about 20 per cent (Table 4).

\section{Discussion}

This study suggested that caries prevention might be possible ecologically using the mutational phase III of Str. mutans, because in both hamsters and rats, the mutational phase III greatly decreased the caries score.

Although hamsters infected with Human-group Str. mutans 10449 phase III were protected from caries lesions, rats were protected only when they were infected with RC-20 phase III, but 10449 phase III did not exhibit any caries-reducing effect at all. This suggests that there is a considerable degree of specificity between Str. mutans and the host.

Str. mutans appeared in the mouth of rats at 19 or 20 days of age. Sato ${ }^{93}$ demonstrated that Str. mutans strains derived from rats were clearly different from strains derived from humans serilogically, and that Str. mutans strains were divided into two main. groups, Human-group and Rat-group, on the basis of their origin. Moreover, Sato et al. ${ }^{10)}$ reported that the Rat-group strain. Str. mutans RC-20 phase I, showed better affinity and produced more caries in rats than the Humangroup strain, Str, mutans 10449 phase I.

In this respect we have recently focused much attention on the biochemical differences between the pilli-like substances, the binding materials, of the cell surfaces of Str. mutans RC-20 and 10449. The adhesive interactions between Str. mutans and tooth surface may be of great ecological significance, and need to be clarified.

Plaque formation and proliferation in phase I strain were extremely inhibited in the presence of phase III in vitro'). In this research, phase III strains of Str. mutans showed the ability to inhibit caries production by wild type strains of Str. mutans in the rat model and by phase I strains of Str. mutans in the hamster model. These findings lend support to the prospect of use of phase III strains in caries prevention.

\section{References}

1) Tsurumizu, T., Sato, M. and Ozaki, F.: A study of mutational phase of Streptococcus mutans : Isolation and properties of mutational phase of Str. mutans, J. Dent. Health, under contribution.

2) Keyes, P. H. and Jordan, H. V.: Periodontal lesions in the hamster. III. Findings related to an infectious and transmissible component, Archs Oral Biol, 9 : 377, 1964.

3) De Stoppelaar, J. D., van Houte, J. and de Moor, C. E.: The presence of dextranforming bacteria, resembling Streptococcus bovis and Strebtococcus sanguis in human plaque, Archs Oral Biol, 12 : 1199, 1967.

4) Keyes, P. H. : A method of recording and scoring gross carious lesions in the molar teeth of syrian hamster, J. Dent. Res., 23 : 439, 1944.

5) Onisi. M. : The mechanism of infection by $S$. mutans in rat caries and the prevention of caries, J. Dent. Health, $25: 2,1975$.

6) Onisi, M., Ozaki, F. and Hamada, M. : Prevention of experimental rat caries III. Influence of casein contents in a cariogenic diet upon caries lesion of pb-marked rats, J. Dent. Health, $16: 85,1966$.

7) Terashima, S. : Differentiation of the two layers of carious dentin by stainning, $J$. Stomatol. Soc., 37 : 279, 1970.

8) Onisi, M., Ozaki, F. and Okono, M.: Prevention of experimental rat caries $\mathrm{N}$. Two different lesion in dentin appeared $\mathrm{nn}$ the fissure caries of rats, J. Dent. Health, 18 : 39, 1968.

9) Sato, M. : Serological properties of Streptococcus mutans from human and some animals, J. Dent. Res., 58 : 461, 1979.

10) Sato, M., Ozaki, F., Okada, S., Tsrumizu, $T$. and Onisi, M. : Cariogenicity in the rat of human type and rat type Streptococcus mutans, J. Dent. Health, 31 : 59, 1981. 
搬要 : Strepptococcus mutans の Mutational phase に関する研究: Str. mutans mutational phase III の制実験におけるう蚛抑制効果について, 倠水 隆*, 福田芳生*, 佐藤 誠*, 尾崎文子**。 Str. mutans mutational phase II株は，動物実験において，う触抑制効果のあることが認められた。 八ムスターを用いた実酸では，口腔内に mutational phase I と phase IIIを投与すると, phase I の 増殖が阻害され，その結果 phase I によるら蝕誘発が抑制された。ラットを用いた実験では，ラッ ト由来の Str. mutans より生した phase III 株は, ラットに常在する Str. mutans の增殖を阻害する 傾向が認められ，ら触誘発に対する抑制効果のあることが明らかにされた。しかし，人由来のStr. mutans より生した phase III 株には, ら触抑制勃果が認められなかった。したがって, Str. mutans と その宿主の間には，特異性の存在することが示唆された。 